\title{
The Use of STEM-Integrated Project-based Learning Models to Improve Learning Outcomes of Junior High School Students
}

\author{
Roudhoutul A. Rochim ${ }^{1, *}$ Prabowo Prabowo ${ }^{1,}$ Mohammad Budiyanto ${ }^{1,}$ \\ Eko Hariyono ${ }^{1,}$ Binar K. Prahani ${ }^{1}$ \\ ${ }^{1}$ Universitas Negeri Surabaya, Indonesia \\ *Corresponding author. Email: roudhoutul.20001@mhs.unesa.ac.id
}

\begin{abstract}
The research objective to get the profile of STEM-integrated PjBL (project-based learning) models for improving learning outcomes of junior high school students. Qualitative descriptive analysis using literature review was conducted to get the profile of STEM-integrated project-based learning models. Research shows that many PjBL models built into STEM are effective in improving science, physics, and math learning outcomes. This article provides recommendations for a learning implementation model that can improve skills in solving learning problems. The application of STEM integrated PjBL to improve students' ability in the first learning outcomes at school can be applied synergistically and sustainably.
\end{abstract}

Keywords: Project-based learning, STEM, Learning outcome.

\section{INTRODUCTION}

In the current era of $5 \mathrm{G}$ technology development, where the orientation of science-based education is directed at change and intensity, learning using STEM Science, Technology, Engineering and Mathematics (STEM) has gained the right momentum and is vital to use [1]. Conventional learning methods are the main factor compared to other factors affecting students' difficulty in solving problems. This method is teacher-centered learning which makes students more likely to memorize. Most students only rely on information from learning textbooks without looking for information from various sources, which resulted in most students not understanding the concept well about what the teacher had conveyed. Understanding the concept is essential in solving physics problems and learning about everyday life phenomena [2].

Based on this situation, educational reform is needed to increase the potential of human resources from the individual side in the IT era, and among the benefits is learning by applying STEM learning innovations [3].

The learner's ability to solve a problem, especially complex problems (for example, real problems in social life), makes it a required skill that learners should have as the next generation of the nation. The application of physics teaching materials using STEM (Science, Technology, Engineering, Mathematics), integrated with $\mathrm{PjBL}$, and combined with the concept of TPACK (Technological Pedagogical Content Knowledge) is expected to increase the validity, ease of application. It can be done to statistically improve students' ability to analyze problems [4].

Implementation of collaborative learning realizes a learning community that learns from each other [5]. The level of depth of teachers' pedagogical understanding of knowledge in $\mathrm{PjBL}$ can be promoted to implement PjBL better. The government has established various models and methods of learning innovation that can improve students' problem-solving skills [2]. STEM (Science, Technology, Engineering, and Mathematics) combines science, technology, engineering, and mathematics components. Skills in conducting STEM learning play an important role in technological developments, and advances in technological development have almost positive and negative impacts [6].

The purpose of STEM education is in line with the requirements of twenty-first-century education. Students have a culture of science and technology resulting from reading, writing, observing, learning and practicing, and pursuing science to develop existing preconditions. Skills to apply to everyday life problems [7]. Scientific learning with a STEM approach is possible in the PjBL (Project Based Learning) learning model. PjBL approach learning with STEM is project-based learning that integrates 
STEM disciplines. The implementation of this research is intended to explain the profile of $\mathrm{PjBL}$ integrated STEM to improve science learning outcomes in junior high school.

\section{METHODS}

A qualitative research strategy was used in completing this research, namely the data collected in relevant scientific works and supporting articles. So that when conducting a literature review on the use of the STEM-integrated project-based learning model $(\mathrm{PjBL})$ to improve the learning outcomes of junior high school students, the researchers tried not to change or manipulate the data or information they have. Sources of data used as references in research are data from previous scientific works, namely research journals and proceedings indexed by Scopus published in 2012-2021 related to the discussion of the research to be analyzed. The data analysis was carried out to obtain valid data for research materials. In this case, the researcher uses two thinking methods, namely the inductive method and the deductive method. The following Figure 1 will explain the stages of data analysis.

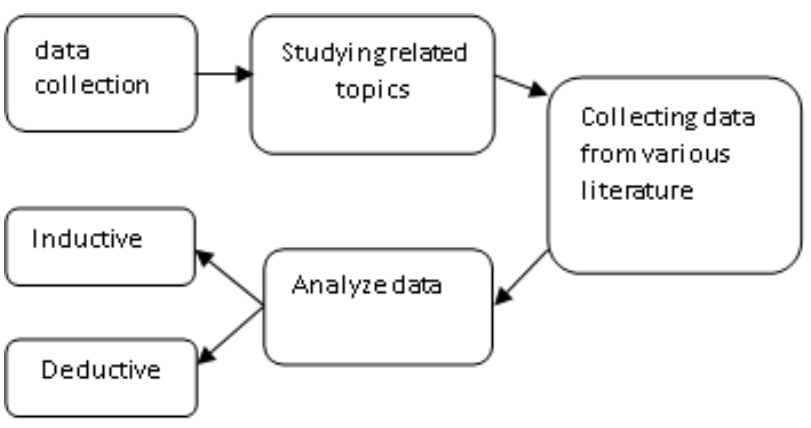

Figure 1 Steps of data analysis in qualitative research.

\section{RESULTS AND DISCUSSION}

Research findings from STEM studies that have been carried out at home and abroad, the results are very good. From 20 articles indexed by Scopus in previous studies, it can be seen that from the research, the STEM model is integrated with $\mathrm{PjBL}$ implementation aims to improve student learning outcomes, publishing throughout 2012-2021 (Table $1)$.

Table 1. Results of journal article analysis

\begin{tabular}{|c|c|c|}
\hline No. & Article & Review of the article \\
\hline 1 & $\begin{array}{l}\text { J. Phys. Conf. Ser., vol. 1464, } \\
\text { no. 1, pp. 2-6, 2020, doi: } \\
\text { 10.1088/1742- } \\
6596 / 1464 / 1 / 012016 .[1]\end{array}$ & $\begin{array}{l}\text { Author: Y B Bhakti, I A D Astuti , I Y Okyranida, D A S Asih , G } \\
\text { Marhento , L Leonard, and A C Yusro } \\
\text { Journal results: Students respond positively to learning by increasing } \\
\text { their understanding, motivation and interest in learning. } \\
\text { Study results: The process of modeling or Simulation activities are based } \\
\text { on known rules formulated using mathematical formulas. So it is hoped } \\
\text { that in the same way, concepts or laws of physics can be expressed as a } \\
\text { concise mathematica formulation. }\end{array}$ \\
\hline 2 & $\begin{array}{l}\text { Pros. Seminar Pend. IPA } \\
\text { Pascasarjana UM Vol. 2, } 2017 \\
\text { [2] }\end{array}$ & $\begin{array}{l}\text { Author: Farah Robi'atul Jauhariyyah, Hadi Suwono, Ibrohim. } \\
\text { Journal results: STEM-PjBL learning opens opportunities for students to } \\
\text { understand contextual learning with complete activities } \\
\text { Study results: PjBL learning with a STEM approach is projectbased } \\
\text { learning by integrating STEM fields that need to be implemented in non- } \\
\text { mathematical/science learning. }\end{array}$ \\
\hline 3 & $\begin{array}{l}\text { PAEDAGOGY J. IImu Pendidik. } \\
\text { dan Psikol., vol. 1, no. 1, pp. } \\
\text { 40-48, 2021. [3] }\end{array}$ & $\begin{array}{l}\text { Author: Suwardi. } \\
\text { Journal results: STEM learning can be applied in several disciplines, } \\
\text { especially in science and mathematics. } \\
\text { Study results: STEM-PjBL learning opens opportunities for students to } \\
\text { understand contextual learning with complete activities. }\end{array}$ \\
\hline
\end{tabular}


$4 . \quad J$. Pendidik. IPA Indones., vol. Author: J. Afriana and A. Fitriani.

5, no. 2, pp. 261-267, 2016,

doi: 10.15294/jpii.v5i2.5493. [4] Journal results: Student responses showed enthusiasm with STEM PjBL learning, which was impressive during learning, and their motivation and interest in learning increased.

Study results: The results of the t-test show that the increase in scientific literacy in the male class and the female class is not significantly different.

5. Int. J. Sci. Math. Educ., vol. 19, Author: Morrison, J. Frost, C. Gotch, A. R. McDuffie, B. Austin, and B. no. 6, pp. 1103-1123, 2021, French.

doi: $\quad 10.1007 / \mathrm{s} 10763-020-$

10108-3. [5]

Journal Results: Recognizing the importance of caring teachers and building strong relationships with students, they will quickly start PBL with the various subject matter.

Study Results: If student teachers have the opportunity to experience authentic research science through reflection, then, in addition to learning on their own and using similar learning in the future, students will be more willing to apply this teaching.

6. Proc. 5th Int. STEM Educ. Author: M. \& O. H. Aksela..

Conf. Integr. Educ. Real world, pp. 9-16, 2019 [6]

Journal Results: Research findings can be taken into consideration by teachers carefully to prepare more in-depth training.

Study Results: Teachers need more training to support their pedagogical content in PjBL learning.

7 J. Balt. Sci. Educ., vol. 17, no. Author: N. M. Siew and N. Ambo.

6, pp. 1017-1033, 2018, doi:

10.33225/jbse/18.17.1017.[7]

Journal Results: Research findings can be taken into consideration by teachers carefully to prepare more in-depth training.

Study Results: Teachers need more training to support their pedagogical content in PjBL learning.

8 Educ. Sci., vol. 11, no. 7, 2021, Author: D. Aguilera and J. Ortiz-Revilla. doi: $10.3390 /$ educsci11070331 [8]

Journal Results: This literature review again shows that both STEM and STEAM learning do not yet have a clear conceptual framework, with broad consensus within the educational sciences.

Study Results: When debating the application of STEAM learning or STEM learning, to develop or enhance student creativity, there will be disagreements with the evidence from empirical studies.

9 Cypriot J. Educ. Sci., vol. 14, Author: Bozkurt, A., Ucar, H., Durak, G. \& Idin, S. no. 3, pp. 374-383, 2019, doi: 10.18844/cjes.v14i3.3447[9]

Journal Results: Research findings stated that in the period 2014 to 2016, there was increasing interest seen in particular the implementation of STEM research, a good direction indicated by the existence of journals that include STEM learning will continue to grow.

Study Results: It is known that there is no interest and interest shown in the data collection and analysis techniques in this research methodology. 


\begin{tabular}{|c|c|c|}
\hline No. & Article & Review of the article \\
\hline 10 & $\begin{array}{l}\text { Eurasia J. Math. Sci. Technol. } \\
\text { Educ., vol. 16, no. 10, 2020, } \\
\text { doi: 10.29333/ejmste/8500. [10] }\end{array}$ & $\begin{array}{l}\text { Author: C. T. Ha, T. T. P. Thao, N. T. Trung, L. T. T. Huong, N. Van } \\
\text { Dinh, and T. Trung. } \\
\text { Journal Results: A wide range of research on basic and cross-sectoral } \\
\text { topics oriented to STEM learning for students, majors in engineering and } \\
\text { computing education. } \\
\text { Study Results: The lack of intra-ASEAN cooperation on the types of } \\
\text { topics in this research is unclear and not effectively implemented in } \\
\text { ASEAN countries. }\end{array}$ \\
\hline 11 & $\begin{array}{l}\text { Al-Bidayah J. Pendidik. Dasar } \\
\text { Islam, vol. 12, no. 1, pp. 139- } \\
\text { 150, 2020, doi: 10.14421/al- } \\
\text { bidayah.v12i1.230. [11] }\end{array}$ & $\begin{array}{l}\text { Author: U. B. Harun } \\
\text { Journal Results: Learning using a STEM-integrated PjBL approach can } \\
\text { improve students' higher-order thinking skills (HOTS). } \\
\text { Study Results: Further investigation of the STEM-PjBL model may follow } \\
\text { the results of this study, such as studies of different levels of the STEM- } \\
\text { PjBL model and the application of different contexts of different subjects, } \\
\text { meta-analysis studies of the effects of STEM-PjBL, studies of the effects } \\
\text { of STEM-PjBL on student learning outcomes, etc. }\end{array}$ \\
\hline 12 & $\begin{array}{l}\text { J. Prim. Educ., vol. 7, no. 1, pp. } \\
\text { 18-24, } 2018, \quad \text { doi: } \\
\text { 10.15294/jpe.v7i1.21382. [12] }\end{array}$ & $\begin{array}{l}\text { Author: T. P. Lestari and S. S. Sumarti } \\
\text { Journal Results: The STEM integrated PjBL can increase students' } \\
\text { creativity than the project-based learning model. } \\
\text { Study Results: Project-based learning models, whether STEM-based or } \\
\text { not, can make the learning process more active, creative and fun. }\end{array}$ \\
\hline 13 & $\begin{array}{l}\text { J. Pendidik. Fis. dan Teknol., } \\
\text { vol. 6, no. 2, p. 246, } 2020 \text {, doi: } \\
\text { 10.29303/jpft.v6i2.2182 [13] }\end{array}$ & $\begin{array}{l}\text { Author: F. Zulaiha and D. Kusuma } \\
\text { Journal Results: It is known that students' scores are } 87 \% \text { Very Strong, } \\
\text { readability test results, and } 80 \% \text { strong practicality test results. } \\
\text { Study Results: limitations of the research: there are suggestions from } \\
\text { students when using the type } 2 \text { learning module so that the writing form } \\
\text { is easier to read, the content presentation is shortened, student activities } \\
\text { are added, it is necessary to give pictures so that they are easy to } \\
\text { understand and clear, and the need to develop other science learning } \\
\text { materials. }\end{array}$ \\
\hline 14 & $\begin{array}{l}\text { J. Pendidik. IPA Indones., vol. } \\
\text { 7, no. 1, pp. 54-65, 2018, doi: } \\
\text { 10.15294/jpii.v7i1.10495. [14] }\end{array}$ & $\begin{array}{l}\text { Author: L. Mutakinati, I. Anwari, and K. Yoshisuke } \\
\text { Journal Results: The study results determine students' critical thinking } \\
\text { skills in STEM education through Project-Based Learning. } \\
\text { Study Results: This study has several limitations that need to be } \\
\text { considered when considering studies and contributions; where the } \\
\text { participants in this study were handpicked based on random distribution, } \\
\text { there was no arrangement in group division. }\end{array}$ \\
\hline 15 & $\begin{array}{l}\text { Berk. Ilm. Pendidik. Fis., vol. 7, } \\
\text { no. 1, p. 1, 2019, doi: } \\
\text { 10.20527/bipf.v7i1.5630. [15] }\end{array}$ & $\begin{array}{l}\text { Author: F. A. Almuharomah, T. Mayasari, and E. Kurniadi. } \\
\text { Journal Results: The integrated STEM Physics module with the "drum" is } \\
\text { useful in improving creative thinking skills and deserves to be a } \\
\text { companion to textbooks at school } \\
\text { Study Results: limitations exist during the overall evaluation; experts in } \\
\text { the field of modules have not implemented relevant STEM learning } \\
\text { steps. }\end{array}$ \\
\hline
\end{tabular}




\begin{tabular}{|c|c|c|}
\hline No. & Article & Review of the article \\
\hline 16 & $\begin{array}{l}\text { Int. J. Sci. Math. Educ., vol. 19, } \\
\text { no. 5, pp. 881-897, 2021, doi: } \\
\text { 10.1007/s10763-020-10103-8. } \\
{[16]}\end{array}$ & $\begin{array}{l}\text { Author: K. Wilson } \\
\text { Journal Results: Several supporting factors and challenges experienced } \\
\text { by junior high schools with low SES implement quality PBL STEM } \\
\text { programs. } \\
\text { Study Results: Limited research on the school culture is built with } \\
\text { teaching using innovative methods-the importance of awareness to } \\
\text { increase the competence of teachers and students to learn actively. }\end{array}$ \\
\hline 17 & $\begin{array}{l}\text { Educ. Sci., vol. 11, no. 7, 2021, } \\
\text { doi: 10.3390/educsci11070353. } \\
{[17]}\end{array}$ & $\begin{array}{l}\text { Author: H. L. T. Thu, T. Tran, T. T. T. Phuong, T. L. T. Tuyet, H. Le Huy, } \\
\text { and T. V. Thi. } \\
\text { Journal Results: Research on STEM High school has grown dramatically } \\
\text { over the past } 5 \text { years, especially in the United States. } \\
\text { Study Results: This study has certain limitations; in particular, the data } \\
\text { were from manually filtered and selected Scopus databases. It depends } \\
\text { on the quality of the input information obtained from a reference source, } \\
\text { namely Scopus. }\end{array}$ \\
\hline 18 & $\begin{array}{l}\text { J. Math. Educ., vol. 11, no. 3, } \\
\text { pp. 333-346, 2020, doi: } \\
\text { 10.22342/JME.11.3.11327.333- } \\
\text { 346. [18] }\end{array}$ & $\begin{array}{l}\text { Author: A. Lasa, J. Abaurrea, and H. Iribas, } \\
\text { Journal Results: This approach will be used in the future to integrate } \\
\text { incorporate different areas of knowledge in interdisciplinary processes, } \\
\text { avoid role asymmetry, and examine constraints and barriers when } \\
\text { implementing interdisciplinary and STEM activities. } \\
\text { Study Results: The limitation of this study lies in that teachers and } \\
\text { researchers must be aware of the inner articulation of mathematical } \\
\text { content in STEM proposals to design learning situations that are faithful } \\
\text { from a purely mathematical point of view. }\end{array}$ \\
\hline 19 & $\begin{array}{l}\text { Int. J. STEM Educ. Sustain., } \\
\text { vol. 1, no. 1, pp. 11-32, 2021, } \\
\text { doi: } 10.53889 / \text { ijses.v1i1.2. [19] }\end{array}$ & $\begin{array}{l}\text { Author: R. Farwati, K. Metafisika, I. Sari, D. S. Sitinjak, D. F. Solikha, } \\
\text { and S. Solfarina } \\
\text { Journal Results: STEM It is used as a teaching method and in } \\
\text { combination using other learning models such as assessment of the } \\
\text { learning process developed into a teaching material, along with its } \\
\text { components and teaching aids. } \\
\text { Study Results: The implementation of STEM research has been carried } \\
\text { out in } 19 \text { provinces in Indonesia with dominance in East Java and West } \\
\text { Java. }\end{array}$ \\
\hline 20 & $\begin{array}{l}\text { J. Pendidik. Fis. Dan Teknol., } \\
\text { vol. 4, no. 2, p. hal. 10, } 2018 . \\
{[20]}\end{array}$ & $\begin{array}{l}\text { Author: D. A. Lestari } \\
\text { Journal Results: learning with integrated worksheets with a STEM } \\
\text { approach can increase students' critical thinking. } \\
\text { Study Results: The research limitations on the interpretation aspect get } \\
\text { the least improvement compared to other aspects, which need to be } \\
\text { developed in future research. }\end{array}$ \\
\hline
\end{tabular}

In accordance with the purpose of this research, which aims to describe the profile of STEMintegrated PjBL to improve science learning outcomes in junior high schools, it can be stated that the profile of the STEM-based learning model STEM integrated projects has been widely carried out at home and abroad with very good results. STEM-integrated project-based learning is the implementation of an approach in implementing education. Science Technology, Engineering, Mathematics are integrated 
in a learning process oriented to solving the problems studied.

The number of articles studied in this research was ten from abroad and ten from within the country. The process steps in STEM integrated project-based learning are: a) Stage 1: Reflection. The guideline for the first stage is to familiarize students with the problem, inspire it, and immediately start an investigation/research. b) Stage 2: research, the second stage is a form of student study. Many learning activities occur at this stage, and increasing students' understanding of learning creates an abstract understanding of the problem. Throughout the research stages, the teachers should frequently discuss to ensure students can develop conceptual presentations relevant to the project that becomes the learning material. c) Stage 3: Discovery, Students begin to explore on their own, for example, the stage of developing students' skills to identify spiritual practices from conception to conception that is not yet known. d) Apply 4: the objective is to test the product/solution and solve problems during the implementation and application phases. In a different case, the student will test the product produced under predetermined conditions and apply it to improve the previous step. e) Stage 5: communication, the final stage of presentation, is a vital step in learning activities for developing the ability to relate and synergize, as well as the skills of giving and receiving feedback that builds learning [10].

Students can also learn from the products they have studied in four areas: science, technology, engineering, and mathematics and made during the YB Bhakti learning process [8]. This condition illustrates that students have mastered the material skills in the science learning process well. In addition, FR Jauhariyyah. [3] the existence of STEM-PjBL Learning opens opportunities for students to understand contextual learning with complete activities; besides, the existence of $\mathrm{PjBL}$ that is integrated with STEM is known to improve learning abilities in the field of science in the process of learning and education [9]. Scientific process skills that aim to improve good thinking skills can improve a sense of independence and problem-solving skills. However, some limitations of project-based learning are found by integrating STEM fields that need to be done by applying non-mathematical/science learning [21]. Uhame Binti Harun [14] stated that implementing the STEM-PjBL-based learning approach can improve students' higher-order thinking skills (HOTS). Research findings that this approach (STEM) will be used in the future to integrate various fields of knowledge in interdisciplinary processes, avoid role asymmetry, and examine constraints and barriers when implementing interdisciplinary and STEM activities [5].
Students can move directly to solve an existing problem in the learning stage using STEM. The implementation of learning with the STEM method needs to be given to students to prepare themselves and improve the various soft skills and hard skills needed in the future [22]. The literature reviewed in the research also supports the implementation of the current curriculum, namely the 2013 (revised) curriculum, which emphasizes students' dynamic nature in the classroom and opens students' horizons and creativity by focusing on mathematical interactions. The 2013 curriculum is a curriculum according to the STEM learning approach [13]. Learners can learn and adapt to the environment [23]. STEM education encourages students to connect learning with the real world. Learners can relate reality in the real world with more complex learning situations and materials outside of their academics [24]. In Indonesia, the innovation research model in the implementation of science learning can be stated that STEM learning can be a learning innovation relevant to the formation of students' character in 21 stcentury skills, namely $4 \mathrm{C}$ skills during the learning independence period [8].

\section{CONCLUSION}

The application of STEM integrated PjBL to improve student's ability in the first school learning outcomes can be applied synergistically and sustainably. Studies show that many PjBL models built into STEM are effective in improving science, physics, and math learning outcomes. Some recommendations for learning models that can train problem-solving skills and integrate PjBL with STEM need to be carried out evenly in all provinces in Indonesia. It requires the implementation of advice and assistance to be applied to the learning community so that all people can enjoy STEM education in the real world of education. Further research and development are needed to improve the application of the STEM-integrated Project Based Learning model so that it is more effective if applied in learning.

\section{AUTHORS' CONTRIBUTIONS}

Roudhoutul A. Rochim as a researcher in reviewing, writing the results, and conducting discussions in this study, Prabowo and Mohammad Budiyanto provided constructive correction assistance to the journal results compiled. Eko Hariyono and Binar Prahani play a role in guiding researchers in the publication and publication of this journal.

\section{ACKNOWLEDGMENT}

To the academic community of the State University of Surabaya who have supported and 
guided the author in completing the material for writing this article,

\section{REFERENCES}

[1] Y B Bhakti , I A D Astuti, I Y Okyranida, D A S Asih, G Marhento, L Leonard, and A C Yusro, "Integrated STEM Project Based Learning Implementation to Improve Student Science Process Skills," J. Phys. Conf. Ser., vol. 1464, no. 1, pp. 2-6, 2020, doi: 10.1088/1742-6596/1464/1/012016.

[2] Farah Robi'atul Jauhariyyah, Hadi Suwono, Ibrohim, "Science, Technology, Engineering and Mathematics Project Based Learning (STEM-PjBL) pada Pembelajaran Sains" Pros. Seminar Pend. IPA Pascasarjana UM Vol. 2, 2017

[3] Churoni Fryda Hajar Ayudha, and Woro Setyarsih, "Studi Literatur : Analisis Praktik Pembelajaran Fisika Di Sma Untuk Melatih Keterampilan Pemecahan Masalah," Jurnal Pendidikan Fisika Undiksha p-ISSN : 25992554 (Print), e-ISSN : 2599-2562 (online) Volume 11 No 1, Mei 2021.

[4] Suwardi, "STEM (Science, Technology, Engineering, And Mathematics) Inovasi dalam Pembelajaran Vokasi Era Merdeka Belajar Abad 21," Paedagogy J. Ilmu Pendidik. dan Psikol., vol. 1, no. 1, pp. 4048, 2021.

[5] J. Afriana and A. Fitriani, "Project based learning integrated to stem to enhance elementary school's students scientific literacy," J. Pendidik. IPA Indones., vol. 5, no. 2, pp. 261-267, 2016, doi: 10.15294/jpii.v5i2.5493.

[6] J. Morrison, J. Frost, C. Gotch, A. R. McDuffie, B. Austin, and B. French, "Teachers' Role in Students' Learning at a Project-Based STEM High School: Implications for Teacher Education," Int. J. Sci. Math. Educ., vol. 19, no. 6, pp. 11031123, 2021, doi: 10.1007/s10763-020-101083.

[7] M. \& O. H. Aksela, "Full papers :PBL in practise :Active teachers' Views of Its' Advantages and Challenges.," Proc. 5th Int. STEM Educ. Conf. Integr. Educ. Real world, pp. 9-16, 2019.

[8] N. M. Siew and N. Ambo, "Development and evaluation of an integrated project-based and stem teaching and learning module on enhancing scientific creativity among fifth graders," J. Balt. Sci. Educ., vol. 17, no. 6, pp. 1017-1033, 2018, doi: 10.33225/jbse/18.17.1017.
[9] D. Aguilera and J. Ortiz-Revilla, "Stem vs. Steam education and student creativity: A systematic literature review," Educ. Sci., vol. 11, no. 7, 2021, doi: 10.3390/educsci11070331.

[10] A. Bozkurt, H. Ucar, G. Durak, and S. Idin, "The current state of the art in STEM research: A systematic review study," Cypriot J. Educ. Sci., vol. 14, no. 3, pp. 374383, 2019, doi: 10.18844/cjes.v14i3.3447.

[11] C. T. Ha, T. T. P. Thao, N. T. Trung, L. T. T. Huong, N. Van Dinh, and T. Trung, "A Bibliometric Review of Research on STEM Education in ASEAN: Science Mapping the Literature in Scopus Database, 2000 to 2019," Eurasia J. Math. Sci. Technol. Educ., vol. 16, no. 10, 2020, doi: 10.29333/ejmste/8500.

[12] U. B. Harun, "Project-Based Learning Integrated To Stem (Stem-Pjbl) To Enhance Arabic Learning Hots-Based," Al-Bidayah J. Pendidik. Dasar Islam, vol. 12, no. 1, pp. 139-150, 2020, doi: 10.14421/albidayah.v12i1.230.

[13] T. P. Lestari and S. S. Sumarti, "STEMBased Project Based Learning Model to Increase Science Process and Creative Thinking Skills of 5th Grade," J. Prim. Educ., vol. 7, no. 1, pp. 18-24, 2018, doi: 10.15294/jpe.v7i1.21382.

[14] F. Zulaiha and D. Kusuma, "Pengembangan Modul Berbasis STEM untuk Siswa SMP," J. Pendidik. Fis. dan Teknol., vol. 6, no. 2, p. 246, 2020, doi: 10.29303/jpft.v6i2.2182.

[15] L. Mutakinati, I. Anwari, and K. Yoshisuke, "Analysis of students' critical thinking skill of middle school through stem education project-based learning," J. Pendidik. IPA Indones., vol. 7, no. 1, pp. 54-65, 2018, doi: 10.15294/jpii.v7i1.10495.

[16] F. A. Almuharomah, T. Mayasari, and E. Kurniadi, "Pengembangan Modul Fisika STEM Terintegrasi Kearifan Lokal 'Beduk' untuk Meningkatkan Kemampuan Berpikir Kreatif Siswa SMP," Berk. Ilm. Pendidik. Fis., vol. 7, no. 1, p. 1, 2019, doi: 10.20527/bipf.v7i1.5630.

[17] K. Wilson, "Exploring the Challenges and Enablers of Implementing a STEM ProjectBased Learning Programme in a Diverse Junior Secondary Context," Int. J. Sci. Math. Educ., vol. 19, no. 5, pp. 881-897, 2021, doi: 10.1007/s10763-020-10103-8.

[18] H. L. T. Thu, T. Tran, T. T. T. Phuong, T. L. T. Tuyet, H. Le Huy, and T. V. Thi, "Two decades of stem education research in middle school: A bibliometrics analysis in scopus 
database (2000-2020)," Educ. Sci., vol. 11, no. 7, 2021, doi: 10.3390/educsci11070353.

[19] A. Lasa, J. Abaurrea, and H. Iribas, "Mathematical Content on STEM Activities," J. Math. Educ., vol. 11, no. 3, pp. 333-346, 2020, doi: 10.22342/JME.11.3.11327.333346.

[20] R. Farwati, K. Metafisika, I. Sari, D. S. Sitinjak, D. F. Solikha, and S. Solfarina, "STEM Education Implementation in Indonesia: A Scoping Review," Int. J. STEM Educ. Sustain., vol. 1, no. 1, pp. 11-32, 2021, doi: 10.53889/ijses.v1i1.2.

[21] D. A. Lestari, "Implementasi LKS Dengan Pendekatan STEM (Science, Technologi, Engineering and Matchmatic) Untuk Meningkatkan Kemampuan Berpikir Kritis Siswa," J. Pendidik. Fis. Dan Teknol., vol. 4, no. 2, p. hal. 10, 2018.

[22] T. Wijayanto, B. Supriadi, and L. Nuraini, "Pengaruh Model Pembelajaran Project Based Learning Dengan Pendekatan Stem Terhadap Hasil Belajar Siswa Sma," J. Pembelajaran Fis., vol. 9, no. 3, p. 113, 2020, doi: 10.19184/jpf.v9i3.18561.

[23] A. R. Firdaus and G. D. S. Rahayu, "Engineering design behavior elementary student's through the STEM approach," $J$. Phys. Conf. Ser., vol. 1511, no. 1, 2020, doi: 10.1088/1742-6596/1511/1/012089.

[24] R. Agustina, I. Huda, and C. Nurmaliah, "Implementasi Pembelajaran STEM pada Materi Sistem Reproduksi Tumbuhan dan Hewan Terhadap Kemampuan Berpikir Ilmiah Peserta Didik SMP," J. Pendidik. Sains Indones., vol. 8, no. 2, pp. 241-256, 2020, doi: 10.24815/jpsi.v8i2.16913.

[25] S. R. G. Fernandes, "Preparing Graduates for Professional Practice: Findings from a Case Study of Project-based Learning (PBL)," Procedia - Soc. Behav. Sci., vol. 139, pp. 219-226, 2014, doi: 10.1016/j.sbspro.2014.08.064. 